\title{
Absence of Troponin in Foot Muscle of Surf Clam Pseudocardium sachalinensis* ${ }^{* 1}$
}

\author{
Satoru Chiba, ${ }^{* 2}$ Takao Ojima, ${ }^{* 3}$ and Kiyoyoshi Nishita ${ }^{* 3,4}$ \\ (Received March, 23 1992)
}

\begin{abstract}
A search for troponin in surf clam foot muscle was made. The muscle, however, seemed to lack troponin, judging from SDS-polyacrylamide gel electrophoresis and immunoblotting of myofibril, native thin filament, and so-called troponin fraction in addition to their effects on $\mathrm{Ca}^{2+}$ sensitivity of $\mathrm{Mg}$-ATPase activity. In contrast, a $160 \mathrm{kDa}$ actin-binding protein was found, though its effects on $\mathrm{Ca}^{2+}$-regulation in muscle contraction are unknown.
\end{abstract}

Molluscan muscles have some characteristic properties. For instance, their actins are easily removable by washing the muscle with low salt buffer solution," ${ }^{\prime \prime}$ and smooth adductor muscles and byssus retractor muscles show an energysaving prolonged state of contraction called "catch", $2-4$ ) Further, the muscles possess two $\mathrm{Ca}^{2+}$-regulatory systems of contraction, namely, the myosin-linked system which is mediated by myosin light chains ${ }^{5-113}$ and the actin-linked system which is mediated by troponin-tropomyosin. ${ }^{12-17)}$ On the other hand, vertebrate skeletal muscles possess the actin-linked system alone, ${ }^{18,1 \theta)}$ in contrast to vertebrate smooth muscles which have been revealed to possess a myosin-linked regulatory system distinct from that of mollusca. ${ }^{20,213}$

Recently, there have been found many actinbinding proteins in vertebrate smooth muscle and non-muscle cells such as leiotonin, ${ }^{22-84}$ ) caldesmon, ${ }^{25,28}$ and calponin ${ }^{27,28)}$ which are thought to be candidates for actin-linked $\mathrm{Ca}^{2+}$. regulatory proteins. These studies suggest that even muscle with the myosin-linked regulatory system possesses actin-linked regulatory protein(s) distinct from troponin.

Since functional troponins of shellfish have been isolated from only the striated and smooth adductor muscles of scallops, ${ }^{16,17)}$ we investigated their existence in another molluscan muscle species, the foot muscle from the surf clam.

\section{Materials and Methods}

Living surf clam was obtained from a local fish market. The foot muscle was cut out and the digestive tract was removed immediately and carefully. The preparation of troponin from the surf clam foot muscle was carried out by the method for akazara scallop Chlamys nipponensis akazara troponin. ${ }^{16,17)}$ Foot muscle $(100 \mathrm{~g})$ was homogenized with $40 \mathrm{mM} \mathrm{KCl}, 10 \mathrm{~mm}$ potassium phosphate ( $\mathrm{pH} 7.0$ ), $1 \mathrm{~mm} \mathrm{MgCl}_{2}, 5 \mathrm{~mm}$ 2-mercaptoethanol, $\quad 0.2 \mu \mathrm{g} / \mathrm{ml}$ leupeptin, $0.2 \mu \mathrm{g} / \mathrm{m} l$ pepstatin, $0.2 \mathrm{~mm} P M S F$, and $1 \mathrm{~mm} \mathrm{NaN}_{3}$ $(300 \mathrm{~m} /)$ in a Waring blender. The homogenate was mixed with the same solution $(700 \mathrm{ml})$, and centrifuged at $10,000 \times \mathrm{g}$ for $10 \mathrm{~min}$. After the washing procedure was repeated twice more, the muscle residues were suspended into $0.4 \mathrm{M}$ $\mathrm{LiCl}\left(\mathrm{pH} \mathrm{5.0)}(1 \mathrm{l})\right.$ and stirred, gently at $4^{\circ} \mathrm{C}$ for $1 \mathrm{~h}$, maintaining pH 5.0 with $0.1 \mathrm{~N} \mathrm{HCl}$. The suspension was centrifuged at $10,000 \times \mathrm{g}$ for $10 \mathrm{~min}$ and the supernatant was subjected to $\left(\mathrm{NH}_{4}\right)_{2} \mathrm{SO}_{4}$ fractionation $(40-60 \%$ saturation). The precipitates formed were collected by centri-

*1 This study was supported by a Grant-in-Aid for Scientific Research from the Ministry of Education, Science, and Culture of Japan.

*2 Present address; Central Research Laboratory, Nippon Suisan Co. Ltd., Kitano, Hachioji, Tokyo 192, Japan (千葉 笪：日本水虐箖式会社中央研究所)。

*3 Department of Fisheries Chemistry, Faculty of Fisheries, Hokkaido University, Minato, Hakodate, Hokkaido 041, Japan (尾島孝舅, 西田清義：北海道大学水座学部水産高分子化学請坐).

* To whom correspondence should be addressed. Abbreviations: TnT, troponin-T; TnI, troponin-I; TnC, troponin-C; SDS-PAGE, sodium dodecyl sulfatepolyacrylamide gel electrophoresis; EGTA, ethylene glycol bis( $\beta$-aminoethylether $)-N, N, N^{\prime}, N^{\prime}$-tetraacetic acid; PMSF, phenylmethylsulfonyl fluoride; $\mathrm{Mr}$, molecular weight; $\mathrm{IgG}$, immunoglobulin $\mathrm{G}$. 
fugation at $10,000 \times \mathrm{g}$ for $10 \mathrm{~min}$, dissolved in and dialyzed against $0.4 \mathrm{M} \mathrm{LiCl}, 1 \mathrm{~mm} \mathrm{NaHCO}_{3}$, and $5 \mathrm{~mm} 2$-mercaptoethanol. The dialyzate was adjusted to $\mathrm{pH} 4.5$ to precipitate tropomyosin. Tropomyosin was further purified by repeating isoelectric precipitation at $\mathrm{pH} 4.5$ and $\left(\mathrm{NH}_{4}\right)_{2} \mathrm{SO}_{4}$ fractionation. On the other hand, the supernatant was fractionated by $40-60 \%\left(\mathrm{NH}_{4}\right)_{2} \mathrm{SO}_{4}$ saturation at $\mathrm{pH} 7.0$ and the precipitates, which were expected to contain troponin, were dissolved in and dialyzed against $1 \mathrm{~mm} \mathrm{NaHCO}$ and $5 \mathrm{~mm}$ 2-mercaptoethanol.

Rabbit myosin and actin were prepared by the methods of Perry ${ }^{20)}$ and Spudich and Watt, ${ }^{30}$ ) respectively. Native thin filaments were prepared from surf clam foot muscle by the method of Goldberg and Lehman. ${ }^{12)}$ Akazara scallop troponin and tropomyosin were prepared as reported previously. ${ }^{18,17)}$ SDS-PAGE was carried out by the method of Porzio and Pearson. ${ }^{31}$ ) Molecular weight was calibrated using a marker protein kit (Mr 30,000-200,000, Sigma). Gels were stained with Coomassie Brilliant Blue R250, and the staining density was measured with a Shimadzu Chromatoscanner CS-9000. Akazara scallop troponin subunits were prepared from SDS-PAGE gels and their antibodies were raised against rabbit by injecting troponin antigens subcutaneously. Immunoblotting was carried out by the method of Towbin et al. ${ }^{32}$ The rabbit antibody bound to the antigen was allowed to react with peroxidase-labeled goat anti-rabbit IgG (Kent Lab.), and detected by coloring reaction with 4-chloro-1-naphthol as reported by Hawks et al. $^{33)}$ Actomyosin Mg-ATPase activity was assayed at $15^{\circ} \mathrm{C}$ in a medium containing $300 \mathrm{~mm}$ $\mathrm{KCl}, 20 \mathrm{mM}$ Tris maleate (pH 6.8), $2 \mathrm{mM} \mathrm{MgCl}_{2}$, $1 \mathrm{~mm}$ ATP, and $0.2 \mathrm{~mm}$ EGTA or $0.2 \mathrm{~mm}$ EGTA plus $0.3 \mathrm{mM} \mathrm{CaCl} \mathrm{C}_{2}$. Inorganic phosphate was measured by the method of Youngburg and Youngburg. ${ }^{34)}$ Protein concentration was determined by the biuret method using bovine serum albumin fraction $\mathrm{V}$ as a standard protein. ${ }^{85)}$

\section{Results and Discussion}

\section{Attempts to Prepare Troponin}

The troponin fraction was prepared as described in "Materials and Methods". When the fraction was dialyzed against $1 \mathrm{mM} \mathrm{NaHCO}_{3}$ and $5 \mathrm{~mm}$ 2-mercaptoethanol, a large amount of precipitate was formed unexpectedly. Therefore, the precipitate was collected by centrifugation at $10,000 \times \mathbf{g}$

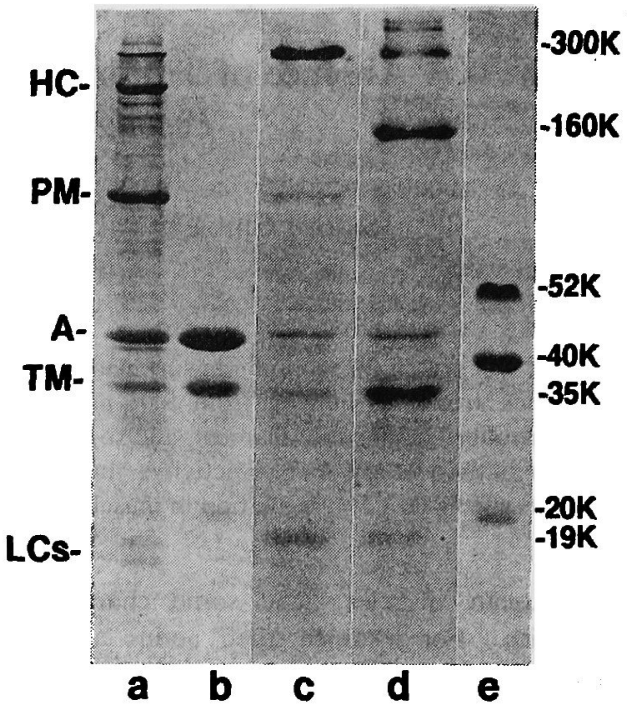

Fig. 1. SDS-polyacrylamide gel electrophoresis of proteins from surf clam foot muscles. Electrophoresis was carried out with $10 \%$ polyacrylamide slab gels containing $0.1 \%$ SDS. a, myofibrils; b, native thin filaments; c, S-fraction; d, P-fraction; e, troponin of akazara scallop striated adductor muscle; HC, myosin heavy chain; PM, paramyosin; A, actin; TM, tropomyosin; LCs, myosin light chains; $300 \mathrm{~K}$, the molecular mass of $300 \mathrm{kDa}$.

for $10 \mathrm{~min}$. The precipitate comprised about $80 \%$ of the total amount of proteins and was named P-fraction. Meanwhile, the supernatant was named S-fraction. These fractions were separately dissolved in $50 \mathrm{mM} \mathrm{KCl}, 1 \mathrm{mM}$ $\mathrm{NaHCO}_{3}$, and $5 \mathrm{~mm}$ 2-mercaptoethanol.

Figure 1 shows the SDS-PAGE patterns of various preparations from surf clam foot muscle. The myofibrils showed many faint bands along with those of subunits of myosin, paramyosin, actin, and tropomyosin. However, the native thin filaments and S- and P-fractions showed several bands with those of actin and tropomyosin subunits. Thus, the native thin filaments and the two fractions showed different combinations of subunit bands from those of the akazara scallop striated $(52,40$, and $20 \mathrm{kDa})$ and smooth adductor (40, 21, and $20 \mathrm{kDa}$ ) troponins, ${ }^{19)}$ and other troponins. ${ }^{38)}$

Further, the myofibrils, native thin filaments, and S- and P-fractions of surf clam foot muscle were subjected to SDS-PAGE (see Fig. 1), followed by immunoblotting using the antisera against akazara scallop troponin subunits which had 


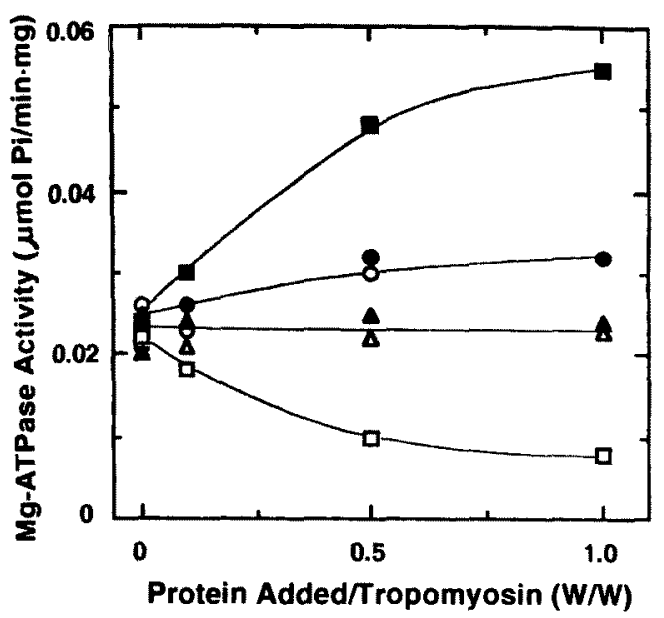

Fig. 2. Effects of $\mathrm{S}$-fraction and P-fraction on the actomyosin $\mathrm{Mg}$-ATPase activity. The $\mathrm{Mg}$ ATPase activity of reconstituted actomyosin with either S-fraction $(0, \theta)$, P-fraction $(\triangle, \Delta)$, or akazara troponin $(\square, E)$ was measured at $15^{\circ} \mathrm{C}$ in a medium containing $30 \mathrm{~mm} \mathrm{KCl}, 20 \mathrm{~mm}$ Tris maleate, $\mathrm{pH} 6.8,2 \mathrm{mM} \mathrm{MgCl}_{2}, 1 \mathrm{~mm}$ ATP, 0.1 $\mathrm{mg} / \mathrm{m} l$ rabbit myosin, $0.05 \mathrm{mg} / \mathrm{m} l$ rabbit $F$ actin, $0.025 \mathrm{mg} / \mathrm{m} /$ surf clam tropomyosin, and S-fraction, P-fraction or akazara scallop troponin $(0-0.025 \mathrm{mg} / \mathrm{ml})$ in the presence of either $0.2 \mathrm{~mm}$ EGTA $(0, \Delta, \square)$ or $0.2 \mathrm{~mm}$ EGTA plus $0.3 \mathrm{mM} \mathrm{CaCl}_{2}(\boldsymbol{O}, \boldsymbol{\Delta}, \boldsymbol{\square})$. been confirmed to cross-react with TnIs, TnTs, and TnCs of ezo-giant scallop Patinopecten yessoensis, blue mussel Mytilus edulis, ark shell Scapharca broughtonii, and oyster Crassostrea gigas. ${ }^{*}$ However, no cross-reactive protein was detected in these preparations (data not shown).

Effect of Surf Clam Proteins on Actomyosin $M g-A T P a s e$ Activity

Since the existence of troponin subunits could not be demonstrated in the $\mathbf{S}$ - and $\mathbf{P}$-fractions and native thin filaments of surf clam foot muscle by SDS-PAGE and immunoblotting, effects of $\mathrm{S}$ - and P-fractions on the actomyosin Mg-ATPase activity were examined. In these experiments, rabbit reconstituted actomyosin was used instead of surf clam foot actomyosin because surf clam myosin itself has $\mathrm{Ca}^{2+}$-regulatory ability. The S- and P-fractions were separately added to rabbit actomyosin along with surf clam foot tropomyosin, and then Mg-ATPase activity was measured in the presence and absence of $\mathrm{Ca}^{2+}$. As shown in Fig. 2, the $\mathrm{S}$-fraction slightly enhanced the activity irrespective of the presence or absence of $\mathrm{Ca}^{2+}$, but the P-fraction did not. Further, no

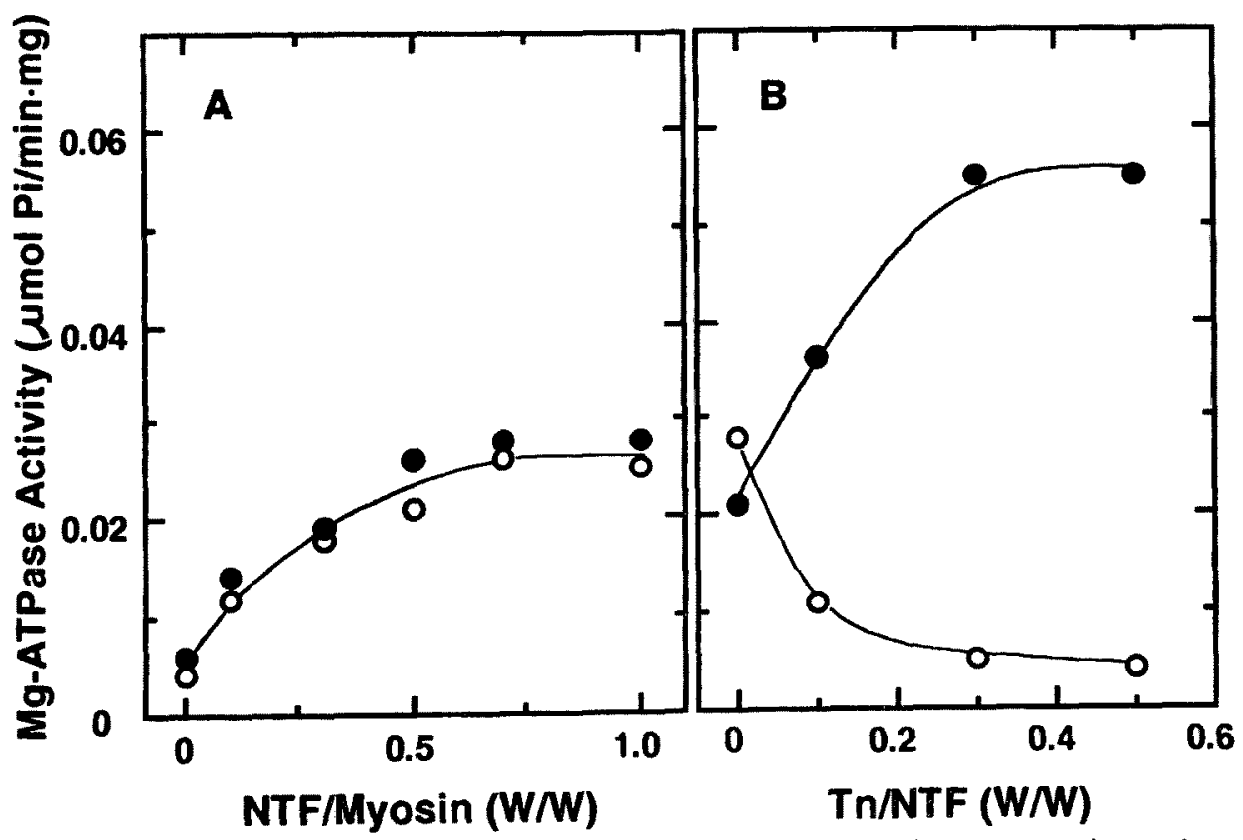

Fig. 3. Effect of surf clam native thin filament with and without akazara troponin on the $\mathrm{Mg}$-ATPase activity of rabbit myosin. The Mg-ATPase activity was measured at $15^{\circ} \mathrm{C}$ in a medium containing $30 \mathrm{mM} \mathrm{KCl}, 20 \mathrm{~mm}$ Tris maleate $(\mathrm{pH} 6.8), 2 \mathrm{~mm} \mathrm{MgCl} \mathrm{M}_{2}, 1 \mathrm{~mm}$ ATP, and the following protein mixture in the presence of either $0.2 \mathrm{mM}$ EGTA (O) or $0.2 \mathrm{~mm}$ EGTA plus $0.3 \mathrm{~mm} \mathrm{CaCl}$ (ب). (A) $0.1 \mathrm{mg} / \mathrm{ml}$ rabbit myosin and $0-0.1 \mathrm{mg} /$ $\mathrm{m} l$ surf clam NTF; (B) $0.1 \mathrm{mg} / \mathrm{ml}$ rabbit myosin, $0.1 \mathrm{mg} / \mathrm{ml}$ surf clam NTF, and $0-0.05$ $\mathrm{mg} / \mathrm{ml}$ akazara scallop striated adductor troponin. NTF, native thin filaments. 


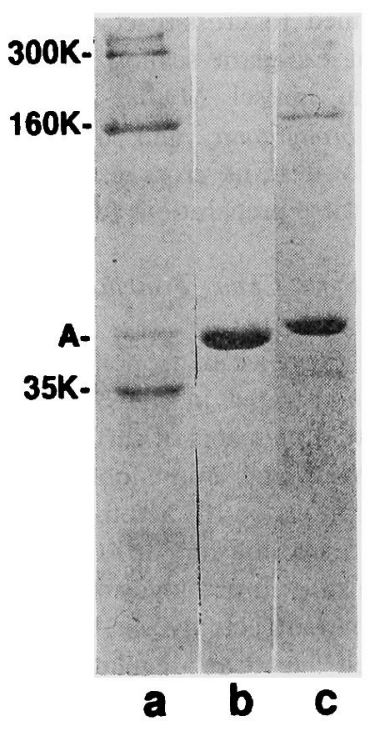

Fig. 4. Binding of protein component in P-fraction with rabbit F-actin. The P-fraction $(0.1 \mathrm{mg} / \mathrm{ml})$ dissolved in $50 \mathrm{~mm} \mathrm{KCl}, 10 \mathrm{~mm}$ Tris- $\mathrm{HCl}(\mathrm{pH} 7.6)$, and $1 \mathrm{mM} \mathrm{MgCl}_{2}$ was mixed with rabbit $\mathrm{F}$-actin $(0.1 \mathrm{mg} / \mathrm{ml})$ and incubated at $0^{\circ} \mathrm{C}$ for $30 \mathrm{~min}$. The mixture was centrifuged at $100,000 \times \mathrm{g}$ for $1 \mathrm{~h}$. The pellet obtained was dissolved in $10 \mathrm{~m}$ urea, $1 \%$ SDS, $0.05 \mathrm{~m}$ Tris- $\mathrm{HCl}$ (pH 8.9), and $0.6 \mathrm{M}$ 2-mercaptoethanol and subjected to SDS-PAGE. a, P-fraction; b, rabbit F-actin; $c$, the pellet.

$\mathrm{Ca}^{2+}$-sensitivity was recovered even when the supernatant of the muscle homogenate or the tropomyosin-free supernatant obtained during preparation was added to the $\mathrm{S}$ - and $\mathrm{P}$-fractions (data not shown). On the other hand, when akazara scallop troponin was added to the rabbit actomyosin-surf clam tropomyosin, high $\mathrm{Ca}^{2+}$ sensitivity was observed.

In addition, native thin filament of surf clam foot muscle was also incapable of conferring $\mathrm{Ca}^{2+}$-sensitivity when complexed with rabbit myosin (Fig. 3A). However, this myosin-native thin filament showed high $\mathrm{Ca}^{2+}$-sensitivity by the further addition of akazara scallop troponin (Fig. 3B).

From these results together with those of SDSPAGE and immunoblotting patterns, it appeared that surf clam foot muscle lacks troponin. Moreover, it is indicated that surf clam tropomyosin retains troponin-binding sites.

\section{Existence of Actin-Binding Protein}

It is well known that vertebrate smooth muscles lack troponin but some of them contain another species of $\mathrm{Ca}^{2+}$-regulatory actin-binding protein. Caldesmon is one of them and is known to cause turbidity formation when bound to F-actin. ${ }^{25,26)}$ Recently, caldesmon-like proteins of $140 \mathrm{kDa}$ were isolated from scallop and cuttlefish ${ }^{37}$ ) and those of $120 \mathrm{kDa}$ from oyster and edible mussel. ${ }^{38)}$

Therefore, the existence of actin-binding protein in the $\mathbf{P}$-fraction was investigated, since the protein precipitates of the fraction occurred from clear solution during dialysis and comprised actin and some other proteins. Thus, the P-fraction was dissolved in $50 \mathrm{mM} \mathrm{KCl}, 10 \mathrm{~mm}$ Tris- $\mathrm{HCl}(\mathrm{pH}$ 7.6), $1 \mathrm{~mm} \mathrm{MgCl}_{2}$, and $0.2 \mathrm{~mm}$ EGTA. The solution was centrifuged at $100,000 \times \mathrm{g}$ for $1 \mathrm{~h}$, and the supernatant obtained was mixed with rabbit $\mathrm{F}$-actin at a ratio of $0.7: 1(\mathrm{w} / \mathrm{w})$, where the precipitates were formed maximally. The precipitates were then collected and subjected to SDS-PAGE. As seen in Fig. 4, a $160 \mathrm{kDa}$ protein was shown to bind to F-actin.

Whether or not this protein is caldesmon or another species of $\mathrm{Ca}^{2+}$-regulatory protein is still unknown, but further studies on its characterization are now underway.

\section{References}

1) O. Otani, S. Hikichi, K. Nishita, T. Sekii, and K. Arai: A loss of actin from shell-fish myofibrils and fish myosin B during wash-treatment. Nippon Suisan Gakkaishi, 49, 415424 (1983).

2) B. M. Twarog: The regulation of catch in molluscan muscle. J. Gen. Physiol., 50, 157-169 (1967).

3) B. M. Twarog: The nature of catch and its control, in "Motility in Cell Function" (ed. by F. A. Pepe, J. W. Sanger, and V. T. Nachmias), Academic Press, New York, 1979, pp. 231-241.

4) R. K. Achazi: Catch muscle. Soc. Gen. Physiol. Ser., 37, 291-308 (1982).

5) J. Kendrick-Jones, W. Lehman, and A. G. Szent-Gyorgyi: Regulation in molluscan muscles. J. Mol. Biol., 54, 313326 (1970).

6) A. G. Szent-Gyorgyi, E. M. Szentkiralyi, and J. KendrickJones: The light chains of scallop myosin as regulatory subunits. J. Mol. Biol., 74, 179-203 (1973).

7) J. Kendrick-Jones, E. M. Szentkiralyi, and A. G. SzentGyorgyi: Regulatory light chains in myosins. J. Mol. Biol., 104, 747-775 (1976).

8) K. Nishita, T. Ojima, and S. Watanabe: Myosin from striated adductor muscle of Chlamys nipponensis akazara. J. Biochem., 86, 663-673 (1979).

9) K. Konno, K. Arai, and S. Watanabe: Myosin-linked calcium regulation in squid mantle muscle. J. Biochem., 86, 1639-1650 (1979).

10) T. Ojima, K. Nishita, and S. Watanabe: Heat $\left(30^{\circ} \mathrm{C}\right)$-desensitization of akazara striated adductor myosin, and its resensitization. J. Biochem., 93, 607-613 (1983).

11) J, Kendrick-Jones and J. M. Scholey: Myosin-linked regulatory systems. J. Musc. Res. Cell Motil,, 2, 347-372 
(1981).

12) A. Goldberg and W. Lehman: Troponin-like proteins from muscles of the scallop, Aequipecten irradians, Biochem. J. $171,413-418$ (1978).

13) T. Tsuchiya, T. Kaneko, and J. J. Matsumoto: Calcium sensitivity of mantle muscle of squid. J. Biochem., 83, 11911193 (1978).

14) W. Lehman, J. F. Head, and P. W. Grant: The stoichiometry and location of troponin I- and troponin C-like proteins in the myofibril of the bay scallop, Aequipecten irradians. Biochem. J., 187, 447-456 (1980),

15) K. Konno: Two calcium regulation systems in squid. $J$. Biochem., 84, 1431-1440 (1987).

16) T. Ojima and $K$. Nishita: Isolation of troponins from striated and smooth adductor muscles of akazara scallop. J. Biochem., 100, 821-824 (1986)

17) T. Ojima and K. Nishita: Troponin from akazara scallop striated adductor muscles. J. Biol. Chem., 261, 16749-16754 (1986).

18) S. Ebashi and F. Ebashi: A new protein component participating in the superprecipitation of myosin B. J. Biochem., $55,604-613$ (1964).

19) S. Ebashi, A. Kodama, and F. Ebashi: Troponin. I. Preparation and physiological function. J. Biochem., 64, 465 477 (1968).

20) A. Sobieszek and J. V. Smail: Myosin-linked calcium regulation in vertebrate smooth muscle. $J$. Mol. Biol., 102 , 75-79 (1976)

21) M. Ikebe, H. Onishi, and S. Watanabe: Phosphorylation and dephosphorylation of a light chain of the chicken gizzard myosin molecule. J. Biochem., 82, 299-302 (1977).

22) S. Ebashi, T. Toyo-oka, and Y. Nonomura: Gizzard troponin. J. Biochem., 78, 859-861 (1975).

23) T. Mikawa, T. Toyo-oka, Y. Nonomura, and S. Ebashi: Essential factor of gizzard 'troponin' fraction. A new type of regulatory protein. I. Biochem., 81, 273-275 (1977).

24) T. Mikawa, Y. Nonomura, M. Hirata, S. Ebashi, and $S$. Kakiuchi: Involvement of an acidic protein in regulation of smooth muscle contraction by the tropomyosin-leiotonin system. J. Biochem., 84, 1633-1636 (1978).

25) K. Sobue, Y. Muramoto, M. Fujita, and S. Kakiuchi: Purification of a calmodulin-binding protein from chicken gizzard that interacts with F-actin. Proc. Natl. Acad. Sci. USA, 78 , 5652-5655 (1981).

26) K. Sobue, K. Morimoto, M. Inui, K. Kanda, and S. Kaki- uchi: Control of actin-myosin interaction of gizzard smooth muscle by calmodulin* and caldesmon-like flip-flop mechanism. Biomed. Res., 3, 188-196 (1982).

27) K. Takahashi, K. Hiwada, and T. Kokubu: Isolation and characterization of a 34000-dalton calmodulin- and F-actinbinding protein from chicken gizzard smooth muscle. Biochem. Biophys. Res. Commun., 141, 20-26 (1986).

28) W. Nishida, M. Abe, K. Takahashi and K. Hiwada: Do thin filaments of smooth muscle contain calponin?: A new method for the preparation. FEBS Letters, 268, 165-168 (1990).

29) S. V. Perry: Myosin adenosinetriphosphatase, in "Methods in Enzymology" (ed. by S. P. Colowick and N. O. Kaplan), Vol. 2, Academic Press, New York, 1955, pp. 582-588.

30) J. A. Spudich and S. Watt: The regulation of rabbit skeletal muscle contraction. J. Biol. Chem., 246, 4866-4871 (1971).

31) M. A. Porzio and A. M. Pearson: Improved resolution of myofibrillar proteins with sodium dodecyl sulfate-polyacrylamide gel electrophoresis. Biochim. Biophys. Acta, 490, 27-34 (1977).

32) H. Towbin, T. Stachelin, and J. Gordon: Electrophoretic transfer of proteins from polyacrylamide gels to nitrocellulose sheets: Procedure and some applications. Proc. Natl. Acad. Sci. USA, 76, 4350-4354 (1979).

33) R. Hawkes, E. Niday, and J. Gordon: A dot-immunobinding assay for monoclonal and other antibodies. Anal. Biochem., 119, 142-147 (1982).

34) G. E. Youngburg and M. V. Youngburg: Phosphorus metabolism. I. A system of blood phosphorus analysis. $J$. Lab. Clin. Med., 16, 158-166 (1930).

35) A. G. Gornall, C. S. Bardawill, and M. M. David: Determination of serum proteins by means of the biuret reaction. J. Biol. Chem., 177, 751-766 (1949).

36) T. Ojima: UI. Regulatory proteins. Troponin and tropomyosin, in "Comparative biochemistry of muscular protein in aquatic animals" (ed. by K. Arai) Suisangaku series, Vol. 76, Koseishakoseikaku, Tokyo, 1990, pp. 51-61.

37) A. Bartegi, A. Fattoum, C. Dagorn, J. Gabrion, and R. Kassab: Isolation, characterization, and immunocytochemical localization of caldesmon-like protein from molluscan striated muscle. Eur. J. Biochem. 185, 589-595 (1989).

38) P. M. Bennett and S. B. Marston: Calcium regulated thin filaments from molluscan catch muscles contain a caldesmonlike regulatory protein. J. Muse. Res. Cell Motil., 11, 302312 (1990). 